\title{
Evaluation of Energy Production Through Solar Photovoltaic Technology for Self-Consumption in the Parish Council of São Bartolomeu de Messines, Portugal - Preliminary Study
}

\author{
Ana Pardal ${ }^{1 *}$, José Pinto ${ }^{2}$, Joana Fernandes ${ }^{3}$ \\ 1 School of Agriculture, Polytechnic Institute of Beja, Portugal \\ 2 Câmara Municipal de Silves, Portugal \\ 3 ADENE - Portuguese Energy Agency, Portugal \\ * Corresponding author e-mail: anap@ipbeja.pt
}

\begin{abstract}
Human survival depends on the continuous supply of energy the demand of which has been steadily increasing. Sharp rises in fuel prices have had major repercussions on the economies of the countries with the greatest energy dependence, and make it imperative to change the attitudes and practices in business and social circles. Today, the problem involves meeting energy needs without negatively affecting the environment, as well as ensuring the wellbeing of current and future generations (sustainable development). The promotion of alternative energy is one of the priorities of the energy and environmental policy of European Union, since it is a decisive factor in reducing greenhouse gases, thus enabling compliance with the Paris agreement. In this work, the contribution of the photovoltaic systems installed for self-consumption in the headquarters of the parish council of São Bartolomeu de Messines, Algarve, Portugal, was assessed. The results indicate that a system with an installed capacity of $6 \mathrm{~kW}$, requiring an investment around $10000 €$, could achieve its economic pay-back in 6.7 years, contributing to a reduction of the annual electricity bill in the building by $60 \%$.
\end{abstract}

Keywords: photovoltaic solar energy, public buildings, sustainability, self-consumption, Algarve/Portugal

\section{INTRODUCTION}

From the point of view of the needs of society, it is obvious that energy generation is an area of major importance, as it is necessary for the development of any human activity. Therefore, the ways in which energy is produced and used, in terms of efficiency, are vital issues, as the existing resources are limited and the energy needs are increasing due to the growth of world population and the development of societies (García-Álvarez et al. 2018).

Fossil fuels remain the main sources in the global energy mix and are associated with the increase of carbon dioxide $\left(\mathrm{CO}_{2}\right)$ emissions. The deployment of renewable energy sources (RES) can play a crucial role in reducing both emissions and fossil fuel dependency (Afonso et al. 2017).
The concern for the state of the environment on the planet first emerged at the highest level in 1972 at the United Nations Conference on the Human Environment (UNCHS) in Stockholm, which resulted in the United Nations Environment Programme (UNEP).

The Kyoto Protocol was the first international legal treaty to explicitly limit quantified greenhouse gas emissions from developed countries.

With the entry of the Paris Agreement into force in 2016, the international community seeks to respond comprehensively and effectively to the urgent need to halt the rise in global average temperatures and resolve the challenges of climate change with determination.

Renewable energy is a sustainable and clean source of energy derived from nature. Renewable energy technology is one of the solutions, which 
produces energy by transforming natural phenomena (or natural resources) into useful energy forms. The interest in the development of solutions, both from the academia and the professional communities around renewable energies has increased noticeably in recent years (Dinçer 2011).

Global warming and the depletion of fossil fuels concerns have prompted the development of renewable energy applications in buildings, such as solar thermal for hot water and space heating, solar air-conditioning, ground source heat pump and solar photovoltaic, etc.

Portugal is a country with scarce endogenous fossil energy resources, namely those that provide most of the energy needs of most developed countries (such as oil, coal and natural gas). The scarcity of fossil resources leads to a high energy dependence from abroad $(75.0 \%$ in 2016$)$, in particular from imports of primary sources of fossil origin. It is therefore important to increase the contribution of renewable energies: hydro, wind, solar, geothermal, and biomass. The energy dependency rate has been decreasing since 2012, with the increase in 2015 due mainly to the growth in imports of coal and natural gas resulting from the increase in consumption in the electro producing sector (DGEG 2016).

In Portugal, laws and regulations have emerged, taking into account the strategies followed by the EU and policies followed globally.

The National Energy Strategy (ENE 2020) with the Horizon 2020 has the following main objectives (among others):

- The reduction of external dependence to $74 \%$ in 2020;

- Guarantee that the commitments made by Portugal in the context of European policies to combat climate change, allowing $60 \%$ of the electricity produced and $31 \%$ of final energy consumption in 2020 to originate from renewable sources and a $20 \%$ reduction in the consumption of final energy under the 20-20-20 energy-climate package;

- Promotion of sustainable development by creating conditions for the fulfilment of the emission reduction targets assumed by Portugal within the European framework (P.C.M. 2010).

The National Action Plan for Renewable Energy under the Directive 2009/28 /EC intends to draw up a sustainable strategy for the exploitation of renewable energies in Portugal aiming at contributing to a competitive and low carbon economy (P.C.M. 2013b).
In 2015, the Council of Ministers Resolution $n^{\circ} 56 / 2015$, of July 30 , established the main national policy instruments in the areas of mitigation and adaptation to climate change - the National Program for Climate Change (PNAC 2020/2030) and the National Strategy for Adaptation to Climate Change (ENAAC 2020). The PNAC 2020/2030 aims at ensuring compliance with the national climate change targets for sectors not covered by the European Emissions Trading Scheme with the National Roadmap of Low Carbon.

The $5^{\text {th }}$ Assessment Report of the Intergovernmental Panel on Climate Change, published in 2014, points out that the scientific evidence relating to the influence of human activity on the climate system is stronger than ever and that global warming is unequivocal. It is, therefore, crucial to monitor and verify the level of emissions and sequestration of greenhouse gases (GHG) of human origin in all sectors of the economy according to international guidelines (Fernandes et al. 2018).

For 2016, the National Action Plan for Energy Efficiency in the period 2013-2016 (PNAEE) estimates a reduction in energy consumption of approximately $8.2 \%$ compared to the average final energy consumption verified in the period between 2001 and 2005, which is close to the EU target of 9\% energy savings by 2016 (Directive 2006/32/ EC). For 2020, the PNAEE sets the overall goal of a $25 \%$ reduction in primary energy consumption and a specific goal for the Public Administration of a $30 \%$ reduction when compared to the consumption average in the period between 2001 and 2005 (P.C.M. 2013a).

\section{ENERGY BY SOLAR PHOTOVOLTAIC TECHNOLOGY}

The photovoltaic (PV) energy consists of the direct conversion of sunlight into electricity. The solar radiation is captured by the PV panels to generate electricity (PV effect) in the form of direct current. The performance of the panels can be roughly defined has the fraction of the solar radiation which is converted into electricity. In the facilities connected to the grid, this energy is transformed into alternating current by an electronic device known as an inverter, and injected to the grid distribution at the point of connection (Santiago Movilla 2013).

Photovoltaic systems use cells (Figure 1) to convert the solar radiation into electricity. The cell consists of one or two layers of a semi-conducting 
material. When light shines on the cell, it creates an electric field across the layers, causing electricity to flow. The greater the intensity of the light, the greater the flow of electricity is.

A typical grid connected photovoltaic solar system consists of three basic elements: photovoltaic module, the inverter DC/AC and the feed-in electricity meter. Batteries and batteries charge controller are also needed when installing an offgrid system (Figure 2). The photovoltaic module consists of photovoltaic cells, i.e., the surfaces that generate electricity, which convert directly solar energy into electricity. These surfaces have no moving parts to wear out or suffer breakdowns and work without the use of fuel, do not produce any vibrations or noise (Sampaio and González 2017; Silveira et al. 2013).

The main advantages of photovoltaic energy generation are:

- Zero $\mathrm{CO}_{2}$ emissions and no noise while producing electricity.
- Systems have a long lifespan of approximately 30 years.

- Wide range of applications, from a small fan or calculator to powering a house, office building or even large generation plants.

- The use and disposal of silicon do not represent any environmental hazard, plus it is an abundant material.

- Only the Sun is needed to produce energy, this resource is free and predictable.

- PV modules can be recycled avoiding the energy consumption used for their production and also contributes reducing their price.

- PV modules require low maintenance.

- Research to improve the efficiency and appearance of cells and systems, while trying to reduce their cost is carried out constantly. In addition, research is being conducted for recycling old PV modules and cells in order to save money mainly by using natural resources and reducing the amount of energy needed to produce new cells (Mundo-Hernández et al. 2014).

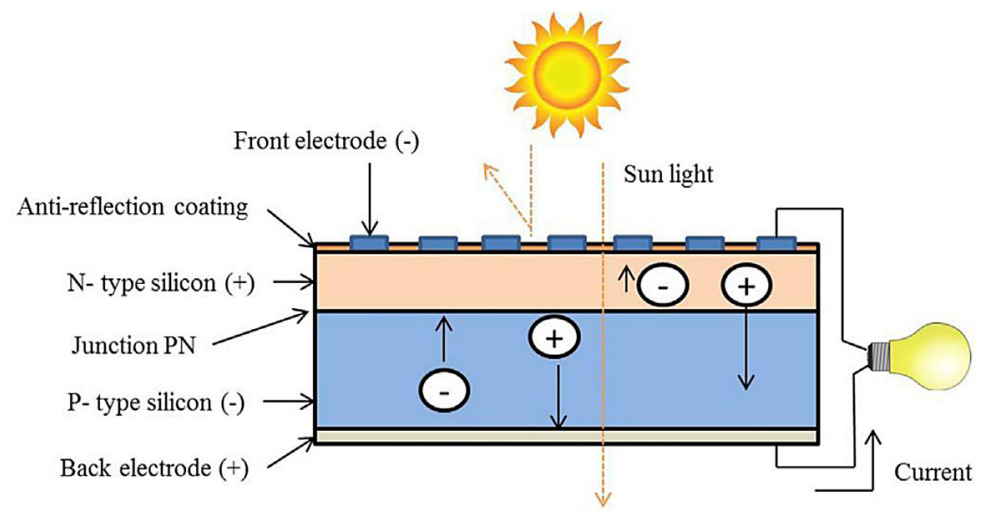

Figure 1. Photovoltaic cell (Sampaio and González 2017).

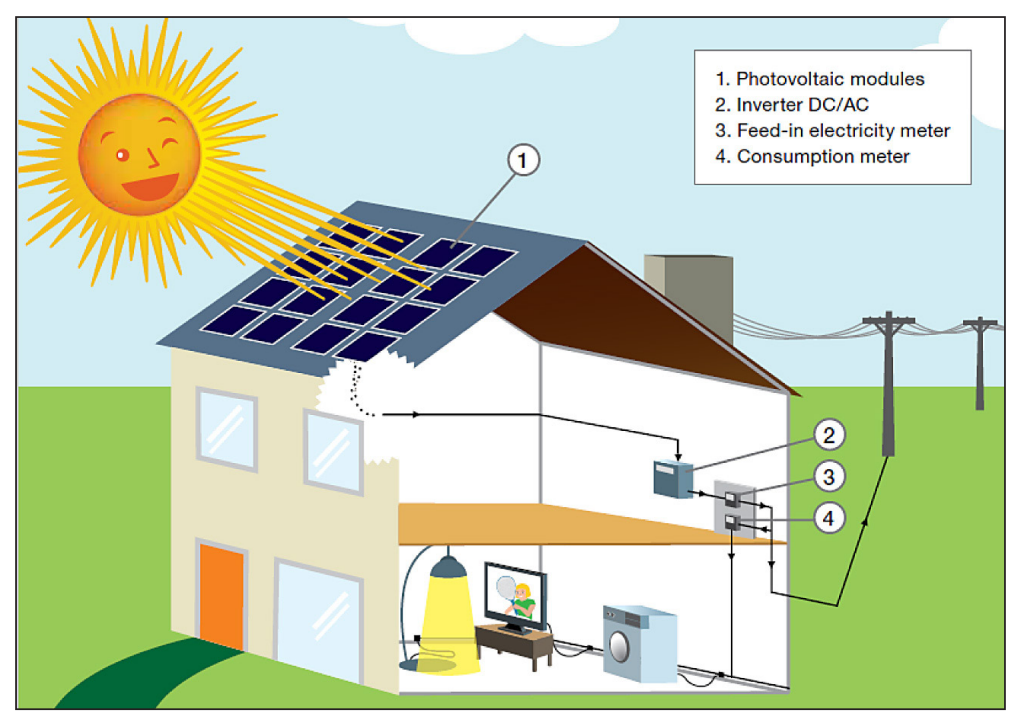

Figure 2. Typical System of photovoltaic solar energy (EPIA nd). 
The main disadvantages of photovoltaic energy generation are:

- A Natural Limit imposed by technical, ecological and land-use limits. Geographical conditions (solar irradiation).

- Available area for installation.

- Considerable investment technology.

- Incorporation of rare materials.

- Skilled installers are needed to build and maintain a PV system.

- Limitations in the availability of systems on the market (Mundo-Hernández et al. 2014; Sampaio and González 2017; Silveira et al. 2013).

Over the past decade, the global installed capacity of solar photovoltaic (PV) has dramatically increased as part of a shift from fossil fuels towards reliable, clean, efficient and sustainable energy (Akbari et al. 2018).

According to the Portuguese legislation (Decree-Law no 153/2014 of October 20 (MAOTE 2014)) for a Self-Consumption Production Unit (SCPU) with an installed capacity of more than $1 \mathrm{MW}$, its installation and entry into operation requires a production and operating license. The systems below $1.5 \mathrm{~kW}$ or not connected to the national electricity distribution grid do not need licensing permits.

The development of alternative, cost effective sources of energy for residential and non-residential buildings has to be a priority. Designing energy efficient and affordable solutions integrated in buildings, dealing with summer and winter climate challenges, represents a very ambitious goal (Aeleneia et al. 2014).

Capturing the solar energy through photovoltaic panels, in order to produce electricity is considered one of the most promising markets in the field of renewable energy. Due to its fast growth perspective and high levels of investment involved, the photovoltaic market is now being increasingly disputed around the world, especially in Europe, China and in the United States (Sampaio and González 2017).

In May 2010, the recast of the Energy Performance of Buildings Directive was published, introducing the Net Zero Energy buildings concept (Commission 2010). The integration of Photovoltaic Systems into buildings becomes an imperative in this context. As it is well-known, Zero Energy Building design does not only mean the adoption of energy efficiency measures, but also the integration of renewable energy systems in order to balance the building energy consumption.
The advantages of PV systems integration in buildings are numerous, resulting in a growing interest in the adoption of these technologies in building design and construction, from the electricity generation perspective, to innovative materials integration in the building envelope (Aeleneia et al. 2014).

\section{CHARACTERIZATION OF THE STUDY AREA}

The Algarve region is located in the south of mainland Portugal and has a geographical situation that is peripheral to other regions. With 4996.8 $\mathrm{km}^{2}$ of area, the population is around 451.000 inhabitants. It has a coast with about $150 \mathrm{~km}$ and is surrounded by the Atlantic Ocean.

The municipality of Silves has a total area of $679 \mathrm{~km}^{2}$ and a resident population around 37.000 inhabitants. The north is bordered by the counties of Odemira and Almodôvar, to the east by Loulé and Albufeira and to the west by Lagoa, Portimão and Monchique, confronting the South with the Atlantic.

The parish of São Bartolomeu de Messines, extends over an area of more than $250 \mathrm{~km}^{2}$, integrated in the municipality of Silves. It is currently the largest parish in the Algarve, with 8,500 inhabitants (Figure 3).

The municipality of Silves has a Mediterranean climate. According to the classification of Emberg, the county of Silves is in the sub-humid to semiarid (near the coast) domains, and according to the Gaussen Xerothermal index there is a type of Meso-Mediterranean climate to attenuated thermomediterranean (100 to 125 biologically dry days). The classification of Köppen reveals that the county is fundamentally under the control of the type of climate Csa that is characterized by being warm temperate, with average temperature of the coldest month between $-3^{\circ} \mathrm{C}$ and $18^{\circ} \mathrm{C}$, with a summer coincident with the season dry and with average temperature of the month hotter than $22^{\circ} \mathrm{C}$ (Tomé 2009).

\section{CHARACTERIZATION OF THE BUILDING (PARISH COUNCIL OF SÃO BARTOLOMEU DE MESSINES)}

\section{Construction}

The current parish council building was inaugurated in 1993 and also houses a social security 


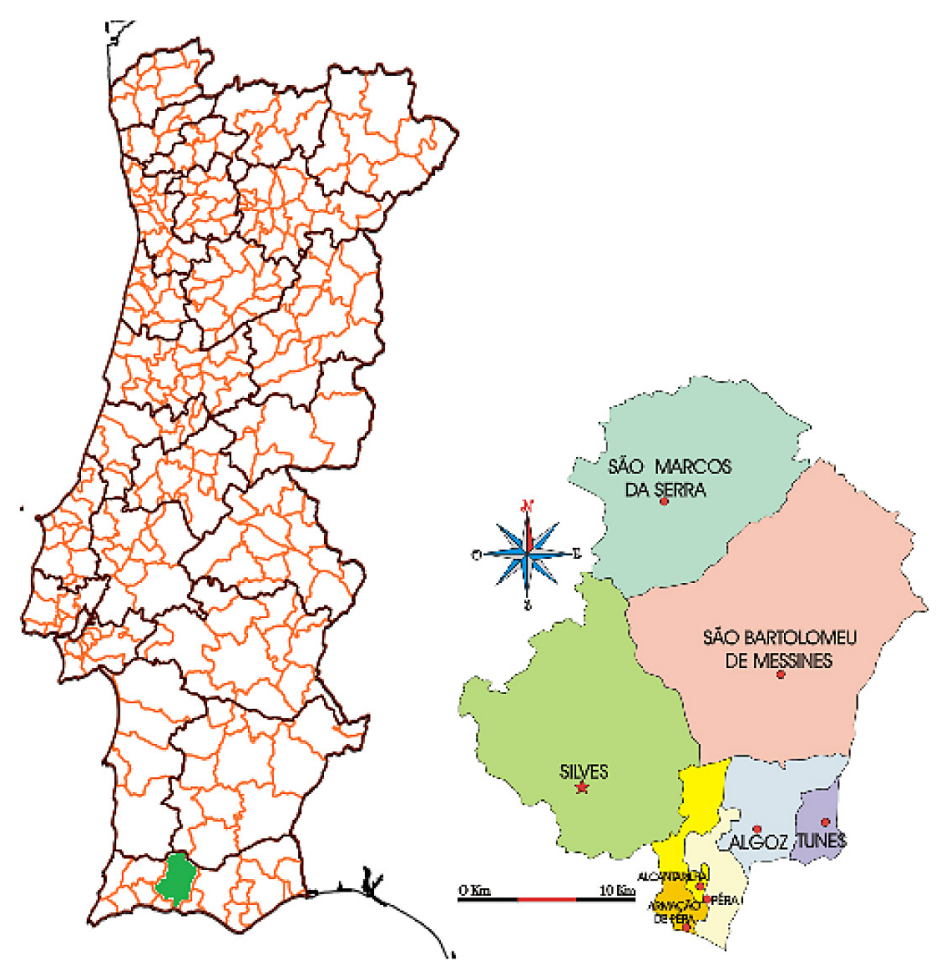

Figure 3. Municipality of Silves (DGT 2017)

delegation. The construction is typical of the late 1980s and early 1990s. It is a one-story building with four-story roofs, where the insulation of ceilings solution with cork panels to condition the region's own thermal oscillations (something unusual for the time) stands out.

It has a structure in reinforced concrete slabs resting on pillars and beams, walls and simple pavements apparently without any thermal insulation. The roof is composed of tiles of Lusa type, with a total area of $300 \mathrm{~m}^{2}$.

The luminosity of the building is quite acceptable, it is important to note that solar radiation does not directly affect the windows with metal frames without thermal cut of single glass, and shading blades were applied for this purpose. The front door is window façade with the roof extending like a porch, shadowing the main entrance (Figure 4).

Usually, seven people work in the building (four at the parish council and three in social security department) although occasionally this number can change for a variety of reasons.

The functioning hours are from 9 a.m. to 5 p.m., Monday to Friday (closed on Saturdays and Sundays).

\section{Solar building exposure}

The building is southwest-oriented, in an area where the surrounding buildings are ground floor or have one storey. The House of the People's building is one of the highest surround buildings but does not overshadow the building of the parish council (Figure 5).

\section{Consumption profile}

The main electricity consumption occurs during working hours, while in non-working hours the bulk of the electricity consumption is due to stand-by and appliances, like the ATM, emergency lights and the UPS.

The electricity consumption profile is similar to many other public offices, with the electrical equipment connected essentially during the day.

In the social security section, it is common for air conditioning to be switched on all year round throughout the day. Some office material, three computers and two printers, as well as lights are used.

In the parish council, the air conditioning is turned on only occasionally (very cold or very hot days). Although natural light is favoured by large windows, office lights are often on. In this part of the building, five computers and printers are in use. There is also a room with two computers for community use, where sometimes training courses are given. Trainees and trainers often employ laptops, using the electrical energy of the building. 


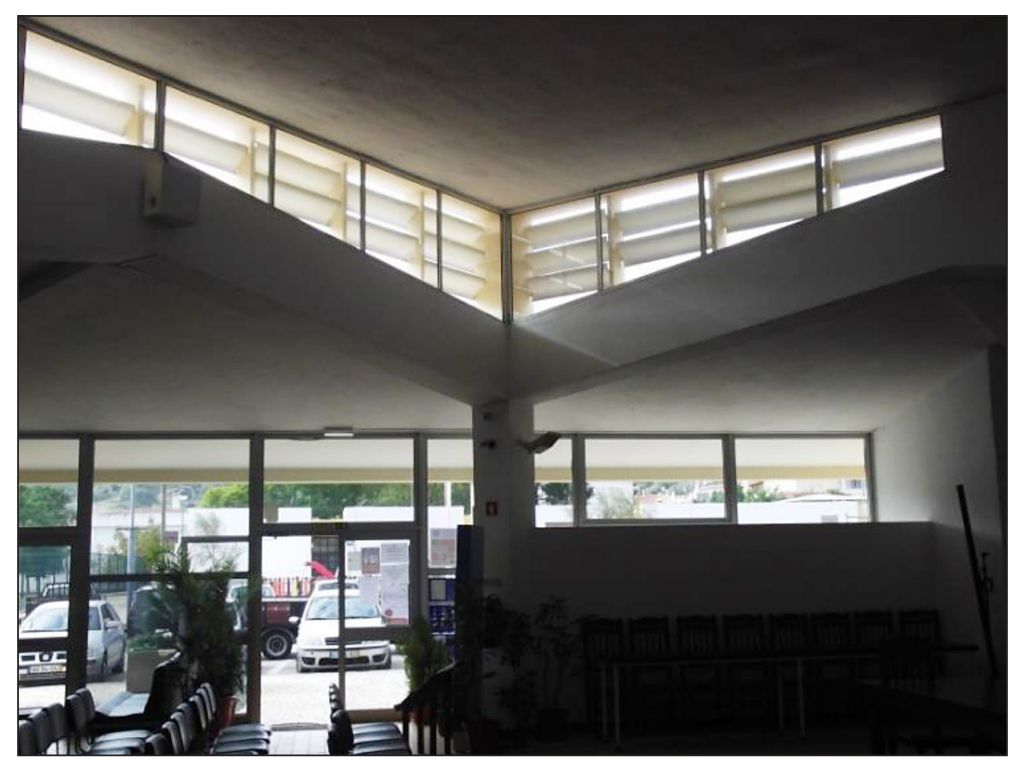

Figure 4. Aspect of the interior of the building.

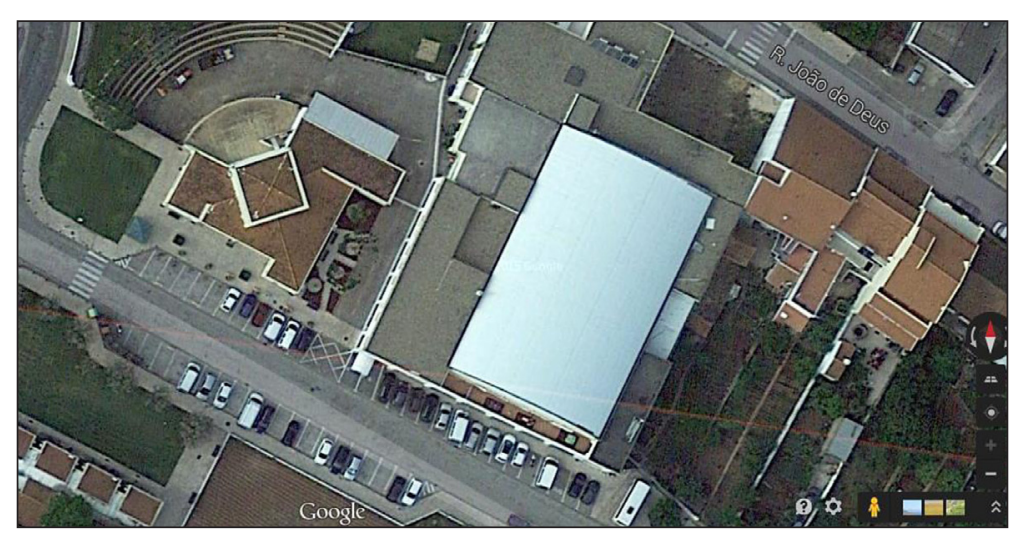

Figure 5. Aerial view of the building of the parish council of São Bartolomeu de Messines (https://www.google.pt/maps/@37.2586284,-8.2907716,103m/data=!3m1!1e3?hl=pt-PT)

\section{Proposed photovoltaic system}

In the present case study, the installation of polycrystalline silicon PV modules is suggested. This type of modules, although characterized by lower efficiency compared to monocrystalline technology, represent a more competitive investment and overall a lower price per $\mathrm{kWh}$.

The proposed system, although for self-consumption, will be connected to the grid, the energy produced will be for consumption in the building itself. The energy produced by the panels is injected into the internal network of the building and is thus instantly available for consumption without any storage.

The system was proposed to maximize automatic consumption, avoiding electricity injection into the national grid and as so avoid compensations to the public utility grid (according to article $25^{\circ}$ of Decree-Law n ${ }^{\circ} .153 / 2014$ of October 20 (MAOTE 2014)).

\section{Data to be analysed}

The building's electricity consumption profile was built based on the historical data from energy bills, 10 months of data from April 2014 to January 2015, and from data collected locally, registering day and night meter readings during three consecutive days, the 25th to the 27th of November.

Daytime consumptions were registered hourly during the building operation period, in order to perceive the consumption profile throughout the day as well as possible consumption peaks.

The night-time consumption was registered observing the last reading of the day, and the first reading of the subsequent one at 9 a.m. 


\section{Characterization of the electrical installation}

Although the parish council building is shared with a social security delegation, the electric counter is the same as a single-phase electromechanical counter.

The electrical installation is the original and it is still in good operating condition. The current installed power is $20.7 \mathrm{kVA}(20.7 \mathrm{~kW}$ calculated with a power factor of 1).

\section{RESULTS AND DISCUSSION}

\section{Consumption analysis}

Figure 6 shows the electricity consumption over the analysed ten-month period, which does not evidence a significant variance over time, except for August, where a consumption peak was registered.

The analysis of the average daily temperatures recorded by the Portuguese Institute of the Sea and the Atmosphere (IPMA), for that period evidenced that the month of July recorded, in most of the days, values of maximum temperature lower than the average of the normal climatological, happening precisely the inverse in the month of August (figure 7 and 8). This may explain the significant difference in the energy consumption.

The electricity consumption profile of the building, built upon the hourly readings in the three consecutive days is presented in Figure 9.

As it can be seen from the recorded readings, the three days present a very similar consumption profile. It is found that - on average $-3.5 \mathrm{kWh}$ are spent per hour of work. This may be a reference value, since November (with $1450 \mathrm{kWh}$ ) is a month that according to the history of consumption is relatively close to the average annual consumption that is $1346.4 \mathrm{kWh}$.

Contrary to what was initially expected, the daytime consumptions ( $28 \mathrm{kWh}$ of recorded average) are very similar to the night-time consumption.

In the analysis, it can be concluded that there may be an energy waste during the night period since during that period only the server, emergency lights, and facade illumination lights and the ATM terminal are connected.

\section{Dimensioning the system}

In the Algarve, most of the installed photovoltaic systems use polycrystalline or monocrystalline modules. Nevertheless, due to its efficiency / investment ratio, there will be a tendency to use mostly polycrystalline models, confirmed by several installers and companies operating in the sector. On the SMA Solar Technology website (https://www.sunnyportal.com/Templates/ PublicPagesPlantList.aspx), it is possible to verify that in the Algarve region the available data indicate that the use of monocrystalline and polycrystalline cells is balanced.

In order to optimize the entire system, it is important to know the solar irradiation at the production local. Each local receives a depleted solar radiation, so it is necessary to know the specific radiation in the study area in order to carry out a more assertive dimensioning.

The PVGIS tool was used to dimension the system, as available at http://re.jrc.ec.europa.eu/ pvgis/apps4/pvest.php?lang=en\&map=europe. This tool allows to estimate the energy production taking into account several variables such as optimal slopes of the panels and the variations of production throughout the year for a given location

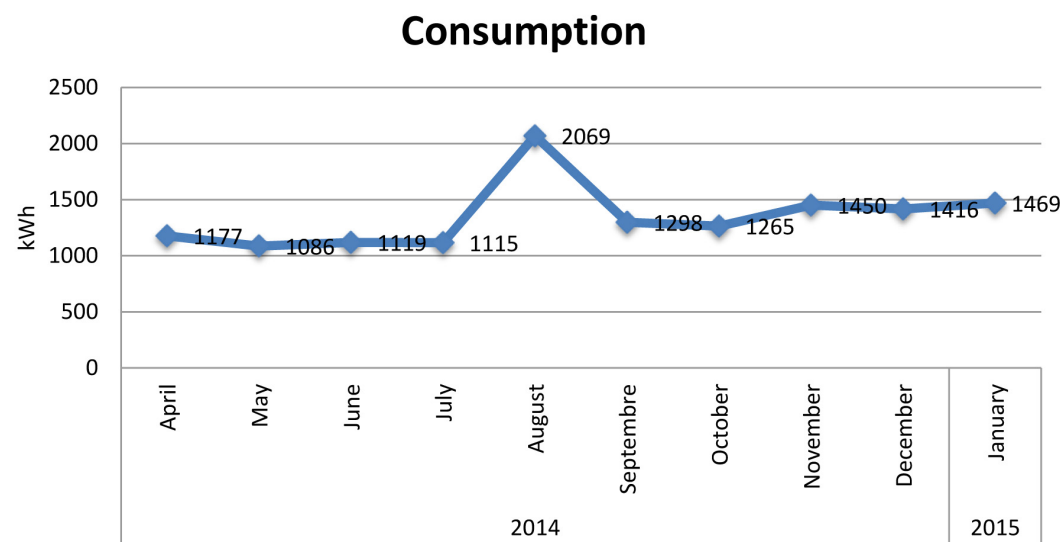

Figure 6. Consumption registered in the parish council building 


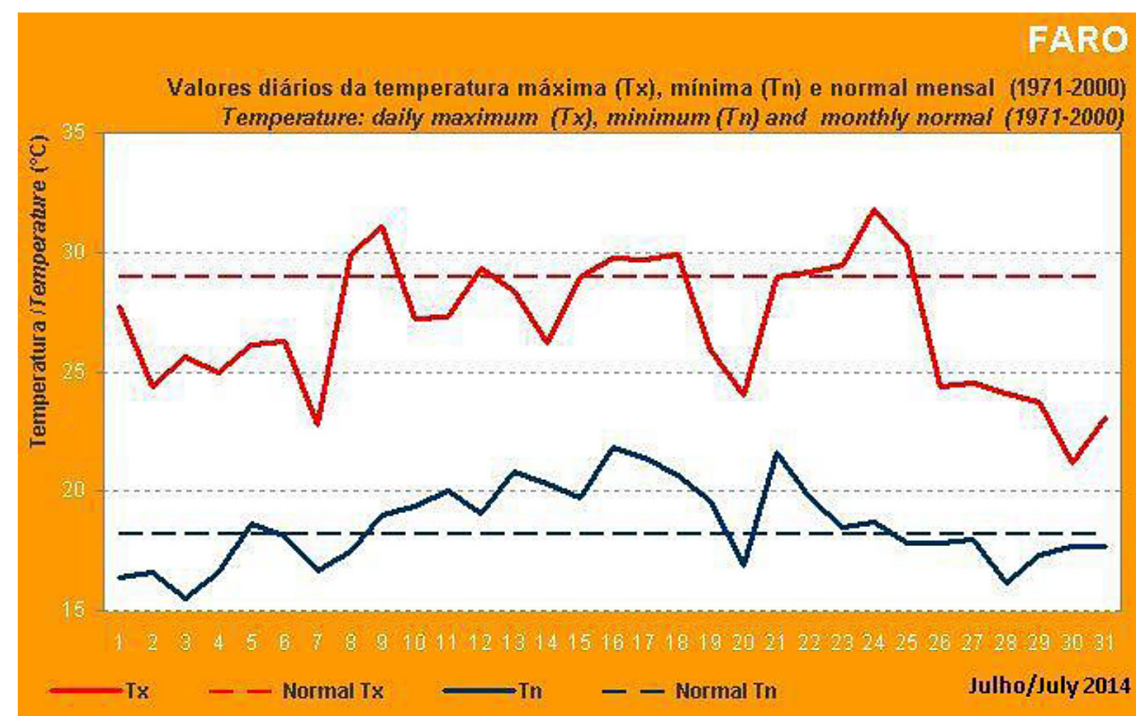

Figure 7. Maximum and minimum temperature recorded in July 2014 (IPMA 2012)

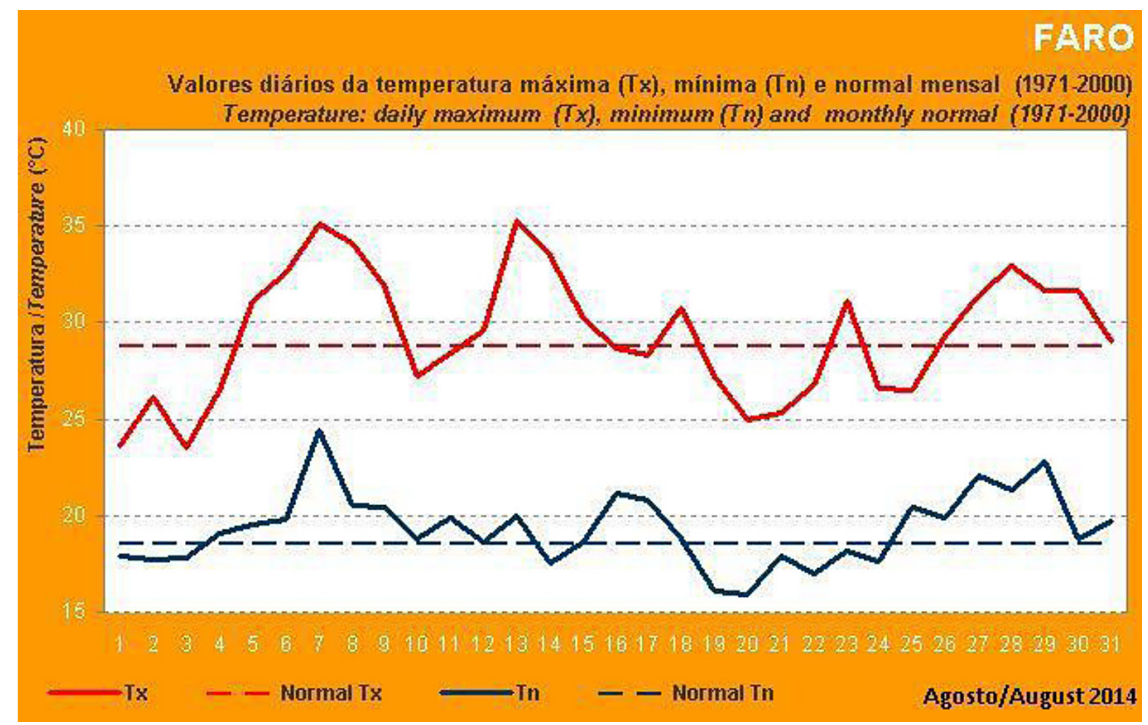

Figure 8. Maximum and minimum temperature recorded in August 2014 (IPMA 2012)

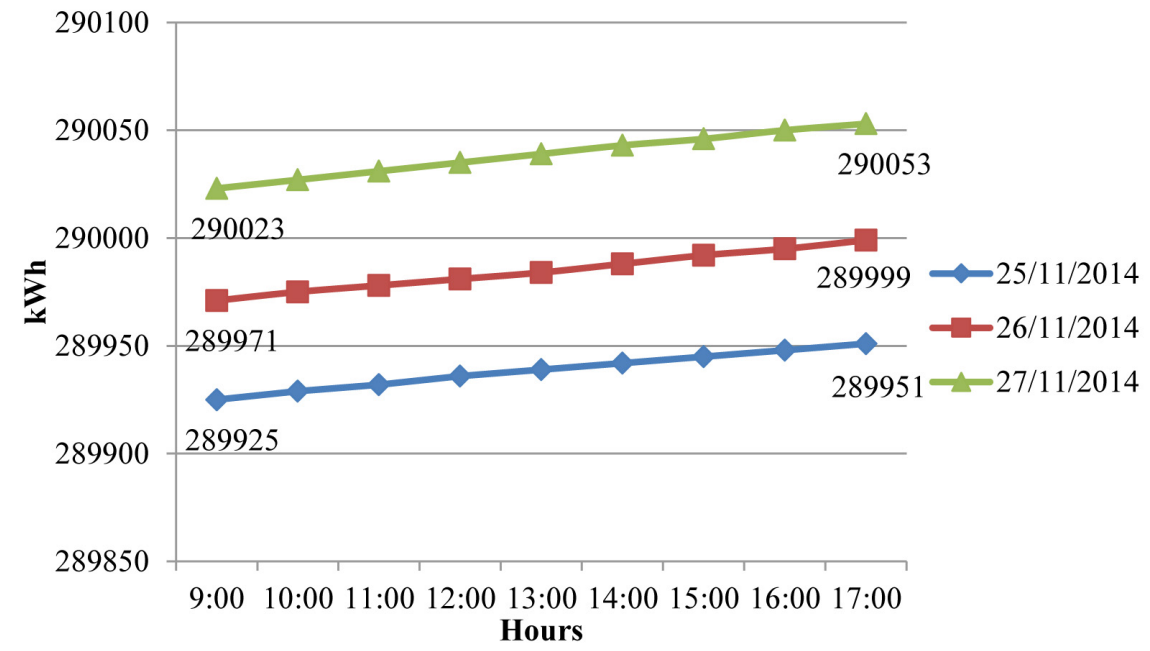

Figure 9. Daily electricity consumption profile 
and the available radiation. Thus, to carry out the dimensioning, the following variables were taken into account:

- Location: $37^{\circ} 15^{\prime} 31$ "North, 8 17’26" West, Elevation: 136 m.s.1

- Solar radiation database used: PVGIS-CMSAF

- Rated power of the PV system: $6.0 \mathrm{~kW}$ (policrystalline silicon)

- Estimated loss due to temperature and low irradiance: $11.5 \%$ (using the local ambient temperature)

- Estimated loss due to angular reflectance effects: $2.6 \%$

- Other losses (cables, inverter, etc.): $14 \%$

- Loss of combined PV system: $25.8 \%$

The dimensioning of the photovoltaic system should take into account the average monthly production, once there is a variation of production throughout the year. For this case study, the simulator for a fixed system indicates that the system to be installed should have $6 \mathrm{~kW}$, and that the modules should be tilted by $33^{\circ}$, with a $0^{\circ}$ orientation, relative to the south quadrant. This power is ideal since it produces an estimated annual average of 26.60 $\mathrm{kWh} /$ day, which is the same as that consumed during a normal working day during working hours. It should be noted that the months of highest production are simultaneously the months where the greatest consumption is registered.

\section{Investment costs and payback period estimate}

For the provision and installation of the system several proposals were requested from specialized service providers.

The system requirements were defined taking into account the results of the previous simulation ( $6 \mathrm{~kW}$, according to the solar radiation simulation).
The budgets received were around $10.000 €$, 12.547.02 $€$ and13.442.47 $€$.

Table 1 presents a simple estimate of the investment return period, considering that:

- In 2014, the parish council with a simple contracted tariff payed each $\mathrm{kWh}$ at $0.1543 €$ (plus VAT at $23 \%$ );

- The annual monthly average consumed was $1.346,4 \mathrm{kWh}$, which should correspond to a total annual consumption of $16,156.8 \mathrm{kWh}$;

- On the basis of the simulations, the annual production of electricity by the photovoltaic system is estimated around $9720 \mathrm{kWh}$.

\section{CONCLUSION}

The links between the environmental and the energy sectors are particularly relevant. Energy production and consumption are directly and indirectly responsible for some of the major negative impacts of human activity on the environment. Most notably, among these are the problems associated with the greenhouse gas emissions to the atmosphere, as well as of other pollutants such as carbon dioxide, sulphur dioxide and nitrogen oxides.

Geographically, the Algarve is a privileged region with respect to the insolation when compared to other regions, presenting the region of São Bartolomeu de Messines as the region with the highest radiation rate $\left(\mathrm{kWh} / \mathrm{m}^{2} /\right.$ month) throughout the year.

With regard to the production of electricity through solar photovoltaic technology, one of its advantages is the correspondence between the hours of greater consumption and the hours of greater production of electric energy. It is estimated that the production of electricity in the selfconsumption regime, using a photovoltaic system, allows the reduction of $60 \%$ of the expenses in the conventional electricity bill, corresponding to an

Table 1. Simple estimate of the return period

\begin{tabular}{|l|c|c|}
\hline & Current system & Photovoltaic system proposed \\
\hline Price $\mathrm{kWh}$ & $0.1543 €($ plus VAT at 23\%) & - \\
\hline Annual consumption kWh & $16,156.8$ & $10,000 €$ \\
\hline Solar panels & - & 9,720 \\
\hline Annual production kWh & - & $(9,720 / 1,656.8)^{\star} 100=60.2 \%$ \\
\hline $\begin{array}{l}\text { \% of the annual production produced by the PV } \\
\text { system }\end{array}$ & \multicolumn{2}{|c|}{$0.1543 \times 9720=1499.80 €$} \\
\hline Possible reduction of costs, per year & \multicolumn{2}{|c|}{$\begin{array}{c}1543 \times 9720 \times 1,23=1844.75 € \\
100000 / 1499,80=6.7\end{array}$} \\
\hline Return period (years) & \multicolumn{2}{|c|}{$1844,75=5.4$} \\
\hline
\end{tabular}


annual saving of around $1500 €$ (plus taxes), assuming that there is no increase in electricity taxes in the coming years. This cost reduction may be even greater if some energy efficiency measures are implemented such as replacing some equipment and adopting good consumer practices.

The estimated investment return period is around 6.7 years, depending on several constraints such as taxes and electricity prices. The financial return may eventually be extended due to the financial compensation that can be paid to the public grid, which would extend the return period for a few months. The system under study is a good option both economically and environmentally. In its expected useful lifetime ( 25 years) it is estimated that the system could prevent the emission of $25.625 \mathrm{~kg}$ of $\mathrm{CO}_{2}$ to the atmosphere.

\section{Acknowledgements}

Publication supported by the Polish Ministry of Science and Higher Education as a part of the program of activities disseminating science from the project „Organization of the First International Science Conference-Ecological and Environmental Engineering”, 26-29 June 2018, Kraków.

\section{REFERENCES}

1. Aeleneia L., Pereira R., Ferreira A., Gonçalves H., Joyce A. 2014. Building Integrated Photovoltaic System with integral thermal storage: a case study. Energy Procedia 58:172-178

2. Afonso T.L., Marques A.C., Fuinhas J.A. 2017. Strategies to make renewable energy sources compatible with economic growth. Energy Strategy Reviews 18:121-126 doi:https://doi.org/10.1016/j. esr.2017.09.014

3. Akbari H., Browne M.C., Ortega A., et al. 2018. Efficient energy storage technologies for photovoltaic systems. Solar Energy doi:https://doi. org/10.1016/j.solener.2018.03.052

4. Commission E. 2010. Directive 2010/31/EU of the European Parliament and of the Council of 19 May 2010 on the energy performance of buildings. Official Journal of the European Union

5. DGEG 2016. Direção Geral de Energia e Geologia. In. http://www.dgeg.gov.pt/ Accessed 10/06/2018.

6. DGT 2017. Direção Geral do Território. In. http:// mapas.dgterritorio.pt/viewer/index.html Accessed 18/06/2018 2018
7. Dinçer F. 2011. The analysis on photovoltaic electricity generation status, potential and policies of the leading countries in solar energy. Renewable and Sustainable Energy Reviews 15:713-720

8. EPIA(nd) Photovoltaic energy-electricity from the sun. European Photovoltaic Industry Association

9. Fernandes A.C., Guerra M.D., Ribeiro R., Rodrigues S. 2018. The State of the Environment Report (REA). In: Ambiente APd (ed).

10. García-Álvarez M.T., Cabeza-García L., Soares I. 2018. Assessment of energy policies to promote photovoltaic generation in the European Union. Energy 151:864-874 doi:https://doi.org/10.1016/j. energy.2018.03.066

11. IPMA 2012. The Portuguese Institute for Sea and Atmosphere. In. http://www.ipma.pt/en/oclima/ normais.clima/ Accessed 19/06/2018.

12. MAOTE 2014. Decreto-Lei n. ${ }^{\circ}$ 153/2014. Diário da República, 1. ${ }^{\mathrm{a}}$ série - N. ${ }^{\circ} 202$ - 20 de outubro de 2014

13. Mundo-Hernández J., de Celis Alonso B., Hernández-Álvarez J., de Celis-Carrillo B. 2014. An overview of solar photovoltaic energy in Mexico and Germany. Renewable and Sustainable Energy Reviews 31:639-649 doi:https://doi.org/10.1016/j. rser.2013.12.029

14. P.C.M. 2010. Estratégia Nacional para a Energia com o horizonte de 2020. Diário da República, 1 . $^{\mathrm{a}}$ série - N. ${ }^{\circ} 73$ - 15 de Abril de 2010 p1289-1296

15. P.C.M. 2013a. Plano Nacional de Ação para a Eficiência Energética (PNAEE). Diário da República, $1 .^{\mathrm{a}}$ série - N. ${ }^{\mathrm{o}} 70$ - 10 de abril de 2013

16. P.C.M. 2013b. Plano Nacional de Ação para as Energias Renováveis (Estratégia para as Energias Renováveis - PNAER 2020). Diário da República, 1. ${ }^{\text {a }}$ série - N. ${ }^{\circ} 70$ - 10 de abril de 2013

17. Sampaio P.G.V, González M.O.A. 2017. Photovoltaic solar energy: Conceptual framework. Renewable and Sustainable Energy Reviews 74:590-601 doi:https://doi.org/10.1016/j.rser.2017.02.081

18. Santiago Movilla L.J.M., Blázquez L.F. 2013. A system dynamics approach for the photovoltaic energy market in Spain. Energy Policy 60:142-154

19. Silveira J.L., Tuna C.E., Lamas W.dQ. 2013. The need of subsidy for the implementation of photovoltaic solar energy as supporting of decentralized electrical power generation in Brazil. Renewable and Sustainable Energy Reviews 20:133-141 doi:https://doi.org/10.1016/j.rser.2012.11.054

20. Tomé R. 2009. Plano Estratégico de Desenvolvimento de Silves - Parte II Enquadramento e Caracterização. 